\title{
METODE PANCASILA DALAM MENANGKAL RADIKALISME
}

\author{
Hastangka $^{1 *}$, Muhammad Ma'ruf ${ }^{2}$ \\ 1) Universitas Mercu Buana Yogyakarta, Yogyakarta, Indonesia \\ 2) Universitas Paramadina, Jakarta, Indonesia \\ * hastangka@mercubuana-yogya.ac.id
}

\begin{abstract}
The rise of the Takfirism phenomenon in society indicates a threatening condition which potentially causes the disintegration of Pancasila. Pancasila as a core value and the basis of national ideology has not been effectively solved the issue of the rise of Takfirism in society. Internal and external factors play an important role in the process of spreading ideas of Takfirism which triggers the emergence of radicalism that eventually leads to acts of terrorism and separatism. The process of searching and finding the right method to build Pancasila as the standard criteria and the validity of values is important to be discussed in the studies and research of Pancasila. This study will explore and describe Pancasila as a method in countering radicalism which is rooted in Takfirism. The method used in this study is a critical study method approach and social phenomenology. The data in this research were obtained through news articles, research reports, study results, scientific journals, and books related to the topic of this research. The result of this research indicates that the Pancasila method as an effort to counter radicalism is very crucial and urgently needed by the state and society in general. Pancasila as a value system and a state system needs to be strengthened by the establishment of the standard criteria and the validity of values that are trustworthy and acknowledged by all social classes.
\end{abstract}

Keywords: Pancasila, values, radicalism

\begin{abstract}
Abstrak
Fenomena berkembangnya paham takfirisme yang berada di lingkungan masyarakat telah menunjukkan kondisi yang rawan dan berpotensi pada disintegrasi Pancasila. Pancasila sebagai sumber nilai dan dasar negara belum dapat berperan secara maksimal dalam menangani persoalan maraknya paham takfirisme di kalangan masyarakat. Faktor internal dan eksternal memiliki peran penting dalam proses berkembangnya paham takfirisme yang melahirkan gerakan dan paham radikalisme yang mengarah pada tindakan terorisme dan perpecahan di masyarakat. Proses pencarian dan penemuan metode yang tepat untuk menjadikan Pancasila sebagai standar kriteria dan validitas nilai menjadi penting untuk dideskripsikan dalam kajian dan penelitian tentang kepancasilaan. Studi ini akan mengeksplorasi dan mendeskripsikan tentang Pancasila menjadi metode dalam menangkal paham radikalisme yang berakar dari paham takfirisme. Metode dalam kajian ini menggunakan pendekatan metode kajian kritis dan fenomenologi sosial. Sumber data yang digunakan dalam penelitian ini diperoleh dari berita, laporan penelitian, hasil kajian, jurnal ilmiah, dan buku yang berkaitan dengan tema penelitian ini. Hasil yang dicapai dalam penelitian ini menunjukkan
\end{abstract}

Sejarah Artikel: Diterima 25 Februari 2021 | Direvisi hingga 19 September 2021

Diterima 24 September 2021 | Publikasikan 30 September 2021 
bahwa metode Pancasila sebagai upaya untuk menangkal radikalisme menjadi sangat penting dan dibutuhkan bagi negara dan masyarakat. Pancasila sebagai sistem nilai dan sistem negara perlu diperkuat dengan pembentukan standar kriteria dan validitas nilai yang dapat dipercaya dan diakui oleh seluruh lapisan masyarakat.

Kata kunci: Pancasila, nilai, radikalisme

\section{PENDAHULUAN}

Ancaman radikalisme dalam negara Pancasila menjadi isu penting di Indonesia dalam kurun waktu 10 tahun terakhir. Berbagai riset dan kajian tentang fenomena berkembangnya paham radikalisme, fundamentalisme, ekstremisme, dan terorisme semakin meningkat. Isu dan fokus perhatian yang menjadi pendekatan dan sudut pandang adalah konflik atas nama agama, dan agama menjadi alat konflik, serta konflik perbedaan pemahaman tentang menata kehidupan keluarga, masyarakat, dan negara. Dalam perspektif ilmu kewarganegaraan, radikalisme menjadi persoalan dan masalah dalam demokrasi karena radikalisme memiliki paham dan nilai-nilai yang tidak berlandaskan pada nilai demokrasi dan nilai-nilai yang ada dalam kewarganegaraan. Prisma volume 39 mengulas topik Radikalisme, Ekstremisme, dan Terorisme dari aspek terminologi dan gejala agresi masyarakat dalam urusan agama yang menempatkan negara sebagai lawan dari agama (Prisma, 2020). Masalah klasik yang selalu timbul di Indonesia ialah masalah hubungan negara dan agama, dan hubungan Pancasila dan agama (Ali, 2009). Hal ini selalu menjadi pertentangan dalam ruang publik dan politik yang pada akhirnya menimbulan kerawanan ideologis. Menurut Kaelan gerakan fundamentalisme pada dasarnya menggunakan dalil ayat $A$ l-Qur'an sebagai pembenar, serta menafsirkan $\mathrm{Al}$ Qur'an dengan melakukan manipulasi makna dan diformulasikan dengan bahasa yang positif dan logis (Kaelan, 2015).

Era reformasi menjadi proses penting dalam berkembang dan masuknya paham paham radikalisme di negara Indonesia. Salah satu indikasi sebagai penyebab dengan mudah masuknya paham radikalisme ialah kontrol negara terhadap masyarakat semakin melemah, pergantian rezim otoriter menjadi demokrasi, dan liberalisasi ideologi menjadi faktor pendorong utama berkembangnya paham radikalisme di Indonesia. Studi tentang radikalisme sudah cukup banyak dan berkembang di Indonesia sejak paska reformasi. Berbagai pendekatan dalam melihat fenomena radikalisme sudah berkembang sampai pada pendekatan interdisipliner dan multidisipliner. Selain itu, lokus kajian tidak hanya pada agenda setting dengan pemahaman agama tetapi juga geopolitik dan ekonomi global. Studi kasus dalam mencermati fenomena radikalisme juga tidak hanya fokus pada kelompok tertentu tetapi juga sudah masuk pada institusi pendidikan seperti sekolah, perguruan tinggi, lembaga negara, organisasi sosial kemasyarakatan, dan institusi TNI/POLRI. Studi yang dilakukan oleh Munip membahas tentang fenomena radikalisme agama di lingkungan sekolah. Radikalisme dalam studi ini menguraikan dua hal dari aspek pemikiran dan aksi. Fenomena radikalisme agama dalam ditunjukkan dari tindakan yang bersifat destruktif-anarkis atas nama agama dari sekelompok orang terhadap pemeluk agama lain atau kelompok agama yang berbeda dan dianggap sesat. Menurut Munip penyebab radikalisme agama karena munculnya berbagai macam penafsiran, pemahaman, aliran, dan sekte dalam satu agama tertentu. Penyebaran paham radikalisme Islam di sekolah pada umumnya terjadi melalui jalur pengkaderan organisasi, melalui 
masjid masjid yang dikuasai oleh kelompok Islam garis keras, melalui majalah, buletin, booklet, dan buku buku. Solusi yang ditawarkan oleh Munip kembali kepada upaya untuk memberikan pemahaman ajaran agama yang benar (Munip, 2012). Studi Qodir melihat radikalisme dalam perspektif agama yang mengarah sebagai gerakan sosial kolektif perlawanan terhadap struktur, sistem, dan nilai-nilai yang dianggap kurang sesuai dengan sistem keyakinan yang dimiliki (Qodir, 2014).

Klaim atas kebenaran dan universal selalu menjadi wacana yang berkembang di masyarakat untuk menentukan arah dan tujuan berbangsa dan bernegara. Fenomena munculnya paham radikalisme di Indonesia berpijak pada dasar dan nilai-nilai yang berkembang dan berakar dari paham Takfirisme lokal dan fenomena terorisme internasional yang memiliki pengaruh bagi kehidupan berbangsa dan bernegara di Indonesia. Pengaruh ini dapat dirasakan oleh masyarakat dan pemerintah. Bentuk pengaruh yang dirasakan ialah munculnya tindakan terorisme, ujaran kebencian pengkafiran, persekusi berbasis paham Takfirisme. Qodir menguraikan tentang konsepsi dan istilah takfir sebagai berikut:

"penggunaan istilah kafir (takfir) bermula dari adanya ketakutan akan datangnya ancaman dari luar Islam seperti pengaruh globalisasi politik, ekonomi, budaya dan teknologi. Selain itu, juga hadir sebagai respons atas munculnya berbagai varian dalam Islam itu sendiri, sehingga merasa perlu melakukan perlawanan secara masif dan global. Islam harus dihadirkan bukan sekedar sebagai alternatif tatanan dunia, tetapi merebut tatanan dunia yang dianggap telah keluar dari kaidah-kaidah hukum Islam dan tauhid, sebab dipimpin oleh para thagut. Sebuah negara akhirnya diposisikan sebagai Negara thagut dan Negara kafir, oleh karena itu negara dapat dilawan bahkan diambil alih dengan cara cara kekerasan sekalipun" (Qodir, 2014, hal. 42).

Isu isu tentang radikalisme sampai sekarang ini melekat pada konsepsi identitas dan politik agama. Dalam konteks Indonesia yang menarik radikalisme menjadi posisi berseberangan dengan nilai-nilai Pancasila. Namun, disisi lain, posisi dan kedudukan Pancasila kembali dipertanyakan karena dianggap belum memiliki 'standar kriteria dan validitas nilai" dalam menjawab persoalan berkembangnya paham radikalisme. Studi sebelumnya yang dilakukan oleh Wicaksono \& Dermawan merumuskan penilaian untuk mengukur tingkat paham radikalisme seseorang dapat dilakukan melalui pendekatan penilaian kepribadian dari 3 komponen antara lain tingkah laku, emosi, dan sikap (H. Wicaksono \& Dermawan, 2020).

Problem berikutnya adanya ambiguitas antara paham Takfirisme agama secara umum dan Pancasila. Kecenderungan maraknya tindak terorisme internasional yang melibatkan teroris lokal sejak digulirkan pergantian rezim di negara negara Timur Tengah sekitar periode tahun 2010 sampai dengan sekarang telah membawa dampak pada masuknya nilai dan paham baru di Indonesia. Proyek pergantian rezim ini dikenal dengan istilah operation regime change (proyek pergantian rezim). Proyek ini mulai dirancang dan dirumuskan di beberapa negara untuk disesuaikan dengan kepentingan-kepentingan dan aktor-aktor negara super power dan perusahaan multi internasional yang menimbulkan industry military complex. Berbagai konflik diciptakan untuk menyerap berbagai kepentingan tertentu. Studi yang dilakukan oleh Wicaksono dan Perwita menjelaskan the military industrial complex, sebagai upaya untuk membangun kemerdekaan militer dan proyek pertahanan nasional di negara Turki sejak pemerintahan 
Erdorgen menjadi bagian dalam mengamankan wilayah yang rawan konflik ( $\mathrm{T}$. Wicaksono \& Perwita, 2020).

Dalam sejarahnya, negara negara Timur Tengah menjadi proyek pergantian rezim sejak perang dunia ke-II karena negara ini memiliki pola hubungan internasional yang masih memegang pola negara induk dan negara peri peri. Negara induk yang dimaksud dimulai dari ekspansi Inggris di Timur Tengah sejak periode perang dunia I. Persaingan antara Inggris dan Turki Usmani berkaitan ekonomi dan kekuasaan (wilayah). Kemudian berdampak pada terbentuknya sistem politik dan model pemerintahan di negara negara Timur Tengah bersifat monarki. Dinamika pergantian kekuasaan yang terjadi di sejumlah negara mayoritas muslim seperti di kawasan Timur Tengah dan Afrika Utara telah menghasilkan sistem kekuasaan dan model pemerintahan yang berbeda beda (Gatra, 2017, hal. 94).

Pada periode berikutnya dilanjutkan oleh negara Amerika Serikat pada masa dan paska perang dunia II, dalam bentuk hegemoni ekonomi dan politik, sampai pada periode sekarang. Dampak dari politik ini, proses demokrasi tidak berkembang dengan baik di negara negara Timur tengah karena kepentingan hegemoni. Selain itu, pembentukan negara Israel oleh Inggris sebagai buffer zone (zona penyangga), untuk mengabadikan konflik di wilayah Timur Tengah menjadi bagian proses konflik nilai, norma, dan wilayah belum bisa diselesaikan dengan baik. Muthohirin menyebutkan bahwa konflik yang terjadi di Timur Tengah telah melibatkan tidak hanya sekedar masalah politik, tetapi juga berkaitan cara pandang terhadap keyakinan beragama. Oleh karena itu, klaim kebenaran agama kerap disuarakan oleh masing masing kubu yang berseteru (Muthohirin, 2019). Tulisan Azra dalam Transformasi Politik Islam Radikalisme, Khilafatisme, dan Demokrasi menguraikan bahwa kekerasan yang berbau atau bernuansa agama bukan terjadi secara kebetulan atau jatuh dari langit. Ia merupakan bagian yang integral dan lanskap kehidupan yang terkait satu dengan yang lainnya ekonomi, politik, sosial, budaya, hubungan internasional (Azra, 2016).

Dalam konteks Indonesia, cikal bakal berkembangnya paham radikalisme bersamaan dengan persaingan Amerika dan Rusia pada era 1980an, dimana Amerika melakukan propaganda dan memobilisasi kekuatan Islam untuk melawan Rusia di kawasan Timur Tengah dan Asia. Misalnya kekuatan Islam pada wilayah Afganistan memunculkan kelompok Taliban. Kelompok ini juga terdapat orang Indonesia yang ikut terlibat. Setelah berakhir di Afganistan, kelompok ini pulang ke Indonesia. Indonesia memberikan ruang para kombatan yang berasal dari Afganistan kembali Indonesia sehingga mereka leluasa mensosialisasikan ide ide dan paham radikal. Benih benih radikal kemudian berkembang menjadi komunitas dan 'dibiarkan" tanpa mendapatkan kontrol negara. Jaringan ini semakin menguat mendapatkan massa dengan jejaring dari berbagai wilayah dan kelompok. Sebab sebab terjadinya paham radikal semakin menguat karena faktor internal yang disebut paham Takfirisme yang difasilitasi oleh kepentingan geopolitik internasional. Kepentingan geopolitik antara lain: keamanan, pertahanan, kelangsungan negara, dan eksistensi negara negara adidaya.

Pada paska reformasi jatuhnya rezim orde baru tahun 1999 tindakan dan aksi radikalisme semakin marak. Puncak gerakan radikalisme ini secara terbuka di mulai dari tragedi bom bali tahun 2002. Kelompok ini merasa memiliki legitimasi untuk mensosialisasikan gagasan dan ide ide mereka secara terbuka di era paska reformasi daripada di era Soeharto. Pandangan Sumarah memperkuat argumen di atas bahwa sejak 
reformasi indikasi keretakan solidaritas nasional makin merebak kepermukaan. Kecenderungan kearah separatisme teritorial, konflik ideologis, benturan etnis, friksi lapisan masyarakat, dan fanatisme religius semakin banyak terjadi (Sumarah, 2011).

Proses demokratisasi di Indonesia menjadi ruang terbuka untuk menjadi legitimasi aktivitas paham radikalisme yang berinteraksi dengan kelompok internasional. Kegiatan ini juga semakin menguat dan berinteraksi dengan proses elektoral melalui mekanisme demokrasi dan pemilu serta pendirian partai politik. Oleh karena itu eksistensi konflik Timur Tengah seperti ISIS (Islamic State of Iraq and Syriah) pada awal periode 2010, telah membawa paham radikalisme ke Indonesia semakin menguat meskipun kekuatan ISIS di Timur Tengah sudah mulai menurun pada periode tahun 2020, proses internalisasi dan penyebaran paham radikal masih eksis di Indonesia melalui berbagai bentuk. Hal ini dapat diindikasikan bahwa ketika ISIS menguat di Timur Tengah dan paham radikalisme juga menguat, begitu sebaliknya ketika ISIS melemah paham radikalisme melemah di berbagai negara. Ketika paska keberhasilan pemberantasan ISIS yang dipimpin oleh Jenderal Qosem Sulaimani sejak 2010 hingga 2020 di Suriah dan Irak maka kekuatan kelompok radikal juga menurun. Pada tahun 2014, pengadilan Mesir menyatakan bahwa ISIS atau kelompok militan negara Islam Irak dan Suriah (ISIS) dan seluruh afiliasinya sebagai organisasi teroris (VOA, 2014).

Keputusan pengadilan Mesir ini menjadi acuan bagi negara negara lain termasuk negara Indonesia untuk memastikan bahwa ISIS dan seluruh afiliasinya dianggap kelompok organisasi yang berbahaya. Persoalan ISIS pada dasarnya persoalan global. Berbagai pemberitaan tentang ISIS pada media media internasional masih muncul yang mengarah pada potensi ancaman keamanan nasional. Sebagaimana diberitakan pada media Russian today yang memberitakan kasus tindakan terorisme di beberapa negara termasuk anggota jaringan terorisme internasional di Jerman (Russian Today, 2021).

Dalam konteks nasional dan lokal di Indonesia terdapat relevansi yang kuat antara menguatnya ISIS dan paham radikalisme, sehingga cara untuk menangani paham radikalisme yang mengarah terorisme tidak lepas dari dinamika dan perkembangan politik ideologi di Timur Tengah. Dalam laporan Gatra mengungkapkan bahwa gelombang revolusi yang melanda Timur Tengah dan Afrika Utara atau yang dikenal dengan Arab Spring memunculkan kekuatan politik Islam. Adu kekuatan politik ideologi yang berakar pada perbedaan golongan, suku, aliran, agama, dan mazhab semakin menguat (Gatra, 2017, hal. 97). Kajian ini menarik untuk dilakukan sebagai upaya untuk merumuskan dan menerjemahkan Pancasila sebagai metode dalam menangkal radikalisme. Dalam konteks negara Indonesia, Pancasila sebagai sistem negara masih lemah dan dianggap mengkhawatirkan karena tidak memiliki kekuatan atau lembaga yang mendukung atas nama negara. Upaya untuk penguatan Pancasila menjadi penting karena selama paska reformasi Pancasila ditafsirkan multi pemahaman.

Isu radikalisme menjadi isu utama dalam proses perjalanan kehidupan bangsa paska reformasi, sejak tragedi bom Bali I dan II pada tahun 2002, kemudian dibentuklah Badan Nasional Penanggulangan Terorisme (BNPT) tahun 2010 menjadi salah satu wujud nyata maraknya tindakan dan aksi terorisme bersumber dari paham radikalisme yang mengarah pada paham Takfirisme. Indonesia merupakan negara majemuk dengan penduduk mayoritas muslim menjadi potensi dan rawan terhadap masuk dan berkembangnya berbagai macam aliran, paham, dan ajaran yang mengarah pada gerakan radikalisme, terorisme, dan ekstrimisme. Posisi dan kondisi sosio-religius masyarakat yang majemuk 
dapat menjadi peluang bagi kelompok yang mengatasnamakan agama untuk memberikan ajaran, paham, dan pengetahuan yang berbeda kepada masyarakat. Keberadaan Pancasila sebagai alat pemersatu bangsa, dasar negara, dan pandangan hidup bangsa yang sudah diletakkan oleh pendiri bangsa kemudian dalam perkembangannya menjadi terkesan dinihilkan dengan munculnya berbagai paham paham yang mengarah pada disintegrasi bangsa secara khusus paham radikalisme. Penelitian ini bertujuan untuk menganalisis dan mendeskripsikan tentang bagaimana Pancasila dapat menjadi metode dalam melakukan verifikasi dan validitas nilai-nilai yang berkembang di masyarakat khususnya nilai-nilai yang dapat berpengaruh pada potensi ancaman disintegrasi bangsa.

\section{METODE PENELITIAN}

Metode penelitian ini menggunakan pendekatan penelitian kualitatif. Bentuk dari penelitian menggunakan kajian kritis dan fenomenologi. Metode kajian kritis dan fenomenologi digunakan untuk menganalisis dan mendokumentasikan. Sumber sumber dan bahan penelitian diperoleh dari media internasional dan nasional, jurnal ilmiah, buku. Penelitian ini dilakukan pada periode Januari- Maret 2021. Kegiatan kajian ini dilakukan dengan studi pustaka dan kajian tematis atas isu isu kebangsaan yang berkembang di Indonesia.

\section{HASIL DAN PEMBAHASAN}

\section{Konsepsi Pancasila}

Secara terminologis, Pancasila dalam Pembukaan UUD 1945 sebagai dasar negara (Bakry, 2003, hal. 11). Kaelan menguraikan bahwa kedudukan Pancasila sebagai pandangan hidup bangsa, dasar negara, dan sistem filsafat menjadi titik pijak penting dalam menata kehidupan berbangsa dan bernegara. Ketika Pancasila diletakkan sebagai pandangan hidup bangsa maka proses perumusan pandangan hidup masyarakat dapat dituangkan dan dilembagakan menjadi pandangan hidup bangsa dan pandangan hidup bangsa dapat dituangkan dan dilembagakan menjadi pandangan hidup negara. Transformasi pandangan hidup masyarakat menjadi pandangan hidup bangsa dan akhirnya menjadi dasar negara sebagai bagian dari proses di dalam Pancasila (Kaelan, 2016). Dalam uraian selanjutnya, Pancasila dijelaskan sebagai sumber dari segala sumber hukum (sumber tertib hukum) Indonesia. Sehingga Pancasila merupakan asas kerohanian tertib hukum (Kaelan, 1996). Pancasila merupakan standar kriteria validitas nilai dalam kehidupan bermasyarakat, berbangsa, dan bernegara. Sila-sila Pancasila yang sudah ada akan mengerucut ke nilai (values) bagi masyarakat dan negara.

Nilai yang akan menjadi titik tolak untuk menjadi standar kriteria dan validitas nilai ialah nilai yang inheren dengan kebenaran yang bisa diterima oleh semua manusia. Nilai-nilai Pancasila pada dasarnya memiliki unsur dan elemen yang mendasar yang bersifat kebaikan, dan memperkuat standar kriteria dan validitas nilai. Sila Ketuhanan Yang Maha Esa, basisnya keyakinan dan kepercayaan kepada nilai-nilai tertinggi tentang kehidupan setelah kematian. Negara yang berdasarkan kepada Ketuhanan Yang Maha Esa ialah mempercayai adanya nilai-nilai tertinggi Ketuhanan yang melintasi nilai-nilai teologis dan keagamaan tertentu. Dalam negara Pancasila, negara tidak menjadikan agama tertentu sebagai dasar negara, tetapi negara mengambil nilai-nilai

\section{JURNAL KEWARGANEGARAAN}


agama sebagai spirit konstitusi (Qodir, 2011). Dengan demikian, tidak lagi perdebatan epistemologis historis yang menganggap Ketuhanan Yang Maha Esa berdasarkan syariat Islam atau agama tertentu. Sila Kedua Kemanusiaan yang Adil dan Beradab, manusia Indonesia secara konstitusional merupakan manusia Indonesia yang berpijak pada nilai-nilai supreme bukan homo faber, tetapi manusia spiritual. Sila ketiga Persatuan Indonesia, sila persatuan ini berhubungan dengan tiga elemen persatuan sesama manusia, persatuan sebagai warga negara Indonesia, dan persatuan internal agama. Manusia yang dimaksud merupakan ciptaan Tuhan bukan makhluk yang terbentuk dan ada begitu saja. Sila Kerakyatan yang dipimpin oleh hikmat kebijaksanaan dalam permusyawaratan/perwakilan. Konsepsi ini mengarah pada demokrasi yang dipimpin oleh hikmat. Hikmat merupakan otoritas nilai yang sudah dirumuskan dan ditetapkan oleh lembaga negara. Dalam hal ini Badan Pembinaan Ideologi Pancasila (BPIP). Badan ini juga perlu memiliki standar kriteria yang ideal untuk menduduki jabatan jabatan yang ada. Misal kompetensi hikmat yang dimaksud sebagai berikut:

Tabel 1. Kompetensi Hikmat

\begin{tabular}{c|l} 
No & \multicolumn{1}{|c}{ Kompetensi Hikmat } \\
\hline 1. & Harus adil \\
\hline 2. & Tahu dan paham hukum \\
Sumber: Analisis Peneliti, 2021
\end{tabular}

Tabel 1. di atas menjabarkan tentang konsepsi hikmat yang dimaksud mulai dari konsepsi adil. Pengertian adil yang dimaksud ialah bisa menjalankan perintah dan larangan baik yang ada di dalam negara, agama, dan nilai-nilai budaya. Sehingga akan dinilai ketika membuat keputusan sudah tahu keputusan keputusan yang bersifat adil untuk kepentingan kemanusiaan, persatuan, kerakyatan, dan keadilan. Maksud tahu dan paham hukum, pemahaman tentang hukum negara dengan baik dan pemahaman hukum yang berkembang di masyarakat. Pancasila merupakan dasar negara Republik Indonesia yang telah diletakkan oleh pendiri bangsa yang tercantum di dalam pembukaan UUDNRI 1945 alenia IV menjadi dasar filsafat dalam kehidupan bernegara. Pasal 2 dalam Undang-Undang Republik Indonesia Nomor 12 Tahun 2011 tentang Pembentukan Peraturan Perundang-Undangan menyatakan bahwa "Pancasila merupakan sumber segala sumber hukum negara". Dalam peraturan perundang undangan secara jelas bahwa kedudukan dan fungsi Pancasila dalam konteks hukum negara Indonesia merupakan sumber dari segala sumber hukum negara. Oleh karena itu, segala bentuk norma dan nilai-nilai yang hendak menjadi norma umum untuk mengatur kehidupan masyarakat hendaknya merujuk pada Pancasila. Persoalan yang muncul di masyarakat yang mengarah pada paham paham yang bertentangan dengan nilai-nilai Pancasila semakin berkembang dan dibiarkan tumbuh menjadi nilai-nilai masyarakat. Dampak terjadi muncul praktek diskriminasi, eksklusifisme, dan kekerasan mengatasnamakan agama tertentu. Situasi dan kondisi seperti ini apabila dibiarkan secara terus menerus dan tidak ada kontrol dari pemerintah akan menimbulkan konflik horizontal. Kehadiran negara dalam mengontrol pelaksanaan nilai-nilai dan proses legitimasi nilai-nilai untuk menjadi norma menjadi penting. Meletakkan Pancasila menjadi metode validitas dan standar kriteria nilai-nilai dalam proses penormaan dalam kehidupan bermasyarakat dan berbangsa menjadi sangat penting. Secara konseptual kerangka Pancasila dijadikan sebagai kriteria dan standar validitas nilai untuk menguji 
berbagai macam nilai-nilai yang berkembang di masyarakat dapat dijabarkan pada bagan sebagai berikut:

Bagan 1. Kerangka Pancasila sebagai kriteria dan Standar Validitas Nilai

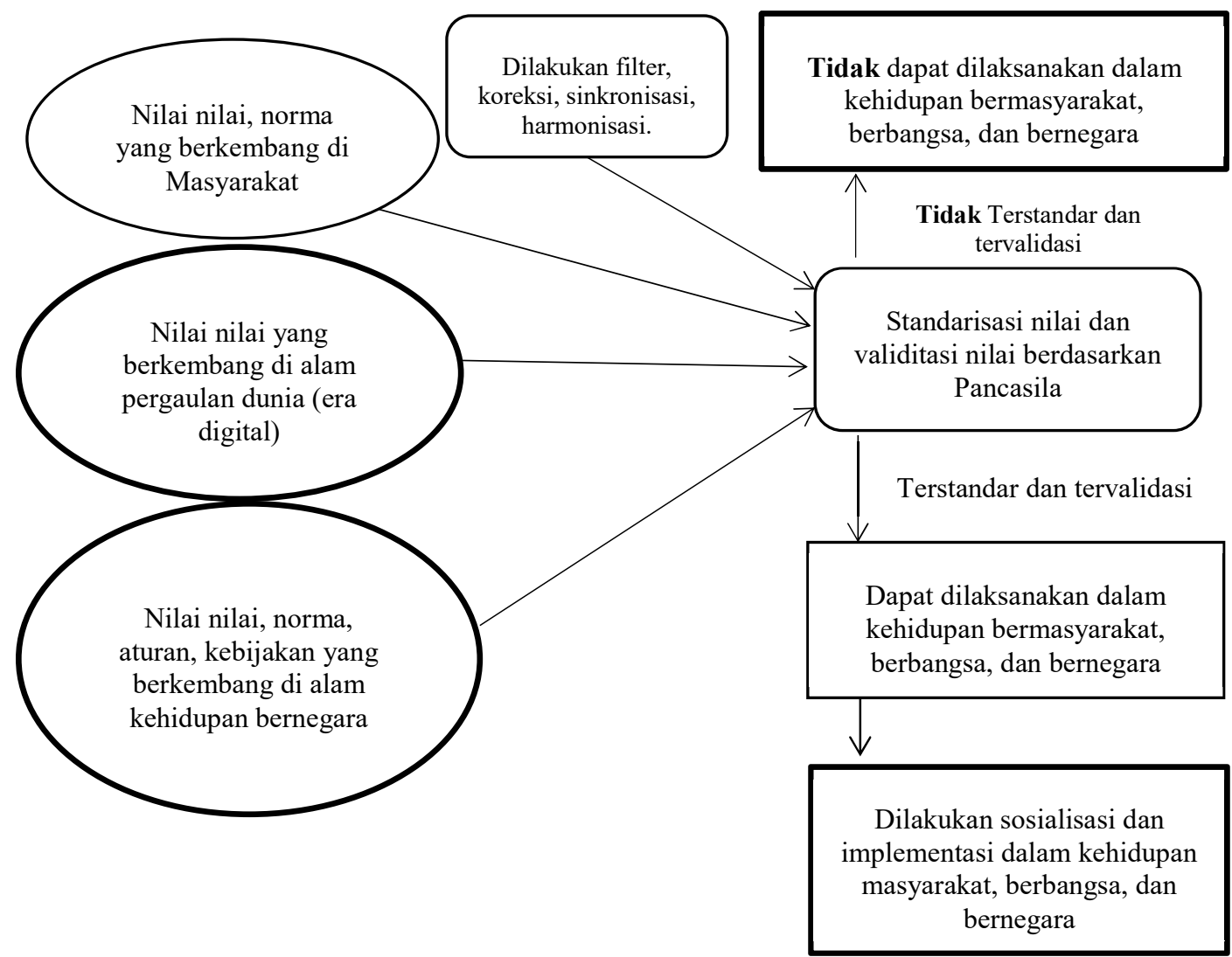

Sumber: Hasil Analisis Peneliti, 2021

Bagan 1 di atas mendeskripsikan tentang proses pengujian nilai dan melakukan standarisasi kriteria dan validitas nilai yang berkembang pada tiga ranah yaitu kehidupan masyarakat, kehidupan pergaulan dunia, dan kehidupan bernegara. Dalam kehidupan masyarakat nilai-nilai dan norma yang berkembang dapat berupa nilai warisan historis dan budaya seperti nilai-nilai budaya dan adat istiadat. Nilai, sistem keyakinan, pandangan hidup, dan norma yang lain yang berkembang dan tumbuh di masyarakat sesuai dengan perkembangan dan perubahan masyarakat seperti nilai dan norma sosial, nilai agama, nilai pergaulan antar anggota masyarakat. Dalam konteks ini, nilai-nilai dan norma di masyarakat dapat saja bertentangan dengan nilai-nilai yang ideal yang sudah menjadi acuan dan pedoman dalam kehidupan bermasyarakat, berbangsa, dan bernegara. Persoalan munculnya paham radikalisme, fanatisme, intoleransi, dan aksi terorisme menjadi salah satu contoh bentuk bentuk nilai yang mengalami perubahan dan perkembangan di masyarakat yang tidak sesuai dengan nilai-nilai Pancasila. Dalam kehidupan pergaulan dunia dapat berbentuk nilai-nilai yang dibawa oleh individu, organisasi, komunitas, atau kelompok yang dapat mempengaruhi cara pandang, pemahaman, dan sistem nilai yang ada di masyarakat. Nilai-nilai hasil dari interaksi pergaulan dunia dapat dibawa melalui teknologi informasi dan media sosial digital seperti youtube, facebook, tiktok, twitter, dan instagram. Nilai-nilai hasil dari pergaulan

\section{JURNAL KEWARGANEGARAAN}


dunia ini dapat mempengaruhi tatanan kehidupan masyarakat. Misalnya masuknya ideologi Wahabi, Ikwanul Muslimin, dan Hizbut Tahrir sebagai bagian dari proses interaksi pergaulan dunia melalui teknologi dan komunikasi. Nilai-nilai dari luar di adopsi dan diajarkan melalui interaksi dan pergaulan dunia dalam bentuk doktrin, dogma, dan penyebaran melalui media sosial digital. Ideologi tersebut berpotensi untuk memperlemah nilai-nilai yang sudah ada termasuk nilai-nilai Pancasila. Gerakan transnasional yang terjadi di Indonesia sampai pada melahirkan partai politik yang berafiliasi dengan gerakan ideologi radikal menjadi bentuk nyata pergerakan dan pergeseran nilai-nilai berbangsa dan bernegara akan diarahkan untuk mencari pengikut dan mengubah jati diri bangsa. Sedangkan nilai-nilai, norma, kebijakan, aturan kehidupan bernegara yang dapat terlihat ialah nilai-nilai yang dimiliki oleh pemimpin dan penyelenggara negara dalam bentuk cara memimpin negara. Nilai-nilai ini terekspresikan dalam kebijakan publik apakah berpihak pada masyarakat, dan kepentingan bangsa dan negara atau kelompok tertentu, kepentingan asing, atau kepentingan kapital/pemodal. Nilai-nilai yang dimiliki pemimpin ini dapat terwujud dari 2 hal yaitu pertama, kriteria dan standar nilai yang digunakan untuk membuat kebijakan politik, sosial, ekonomi, pendidikan, hukum yang berdampak pada masyarakat. Kedua, kriteria dan standar nilai yang digunakan untuk membuat regulasi dan peraturan perundang undangan. Munculnya berbagai macam peraturan perundang undangan yang bertentangan dengan Pancasila dan Undang Undang Dasar Negara Republik Indonesia dapat memperlihatkan bahwa kriteria dan standar nilai yang digunakan dalam merumuskan dan pembuat peraturan perundang undangan baik ditingkat pusat maupun daerah masih belum sesuai dengan nilai-nilai Pancasila. Misalnya, perda syariah, kebijakan wisata halal, kebijakan Bank Syariah, kebijakan hijabisasi pegawai negara atau siswi non muslim pada sekolah negeri, perda injili, Undang Undang Sumber Daya Alam yang justru berpotensi pada disintegrasi bangsa dan tidak menjamin terwujudnya keadilan sosial.

Paham radikalisme yang berkembang di Indonesia dan sudah masuk ke berbagai aspek kehidupan masyarakat, berbangsa, dan bernegara sebagai salah satu akibat dari tidak adanya standarisasi dan validasi nilai-nilai kehidupan bermasyarakat, berbangsa, dan bernegara. Pancasila sejak paska reformasi terabaikan. Pancasila hanya sekedar dijadikan simbol dan jargon sosial dan politik tetapi bukan menjadi dasar dan pandangan hidup bangsa yang harus diaktualisasikan. Untuk itu, konsepsi Pancasila perlu diletakkan sebagai proses berbangsa dan bernegara dengan menjadikan Pancasila sebagai aspek penormaan dan uji sahih atas nilai-nilai yang berkembang di masyarakat.

\section{Paham dan Konsep Radikalisme}

Istilah radikalisme di Indonesia dipahami dalam berbagai dimensi. Radikalisme dalam ranah keilmuan dapat dilihat dari aspek bahasa, filsafat, aliran, nilai, dan sosial. Kusman meletakkan konsep radikalisme sebagai kapasitas berpikir kritis dalam memahami kondisi sosial yang ada beserta kemampuan untuk membongkar ketimpangan relasi kekuasaan yang beroperasi dalam realitas sosial (Kusman, 2020, hal. 17). Pandangan Sudjito dan Muhaimin melihat konsep radikal dipahami sebagai suatu sikap ekstrim atau keyakinan yang tidak memberikan ruang toleransi kepada kelompok yang tidak sepaham dengannya (Sudjito \& Muhaimin, 2018). Radikalisme yang dimaksud disini dalam ruang lingkup radikalisme yang berpotensi dan melakukan tindakan teroris yang melanggar hukum dan melawan nilai-nilai luhur Pancasila. Dalam 
konteks Undang Undang radikalisme diberikan batasan sesuatu yang membahayakan ideologi negara dan keamanan negara (Undang-Undang Republik Indonesia Nomor 5 Tahun 2018 tentang Perubahan Atas Undang-Undang Nomor 15 Tahun 2003 tentang Penetapan Peraturan Pemerintah Pengganti Undang-Undang Nomor 1 Tahun 2002 tentang Pemberantasan Tindak Pidana Terorisme Menjadi Undang-Undang).

Paham radikalisme sering menjadi pokok bahasan umum. Paham radikalisme memiliki unsur unsur sebagai berikut: 1. Memiliki dan meyakini paham Takfirisme, paham Takfirisme yang dimaksud ialah mengkafirkan dan menghalalkan darah kelompok lain dan menganggap kelompoknya paling benar; 2. Melakukan tindak kriminal berupa melanggar aturan hukum yang berlaku di Indonesia dan nilai-nilai Pancasila; 3. Mensosialisasikan kelompok yang dikafirkan secara terbuka melalui organisasi dan wadah wadah yang dibuat atau dilegalkan oleh pemerintah, 4. Melakukan upaya upaya dan tindakan tindakan dengan mengambil peran atau otoritas negara atas nama keyakinan takfirisme yang dimaksud. Akar dari radikalisme yang berkembang di Indonesia berpijak pada paham Takfirisme yang menggejala di kelompok kelompok Islam yang berpaham aliran khawarij dan Wahabi ekstrim. Radikal yang dimaksud merupakan term politik dan kasus umum. Dalam studi yang lain radikalisme Islam dianggap sebuah proses historis. Di Indonesia jejak awal munculnya "Islam yang radikal" dapat ditelusuri dari munculnya Darul Islam (DI) di beberapa kota pada era kemerdekaan. Kemudian partai politik Majelis Syura Muslimin Indonesia (Masyumi) yang banyak berinteraksi dengan berbagai jaringan transnasional dengan beberapa gerakan radikal Islam di Timur Tengah. Misalnya, gerakan Wahabi di Arab Saudi, Ikhwanul Muslimin di Timur Tengah, kemudian Hizbut-Tahrir dari Yordania (Umar, 2010).

Kasus yang dapat diamati terkait dengan praktek paham radikalisme keagamaan yang bersumber dari ajaran Takfirisme ialah pertama, pemotongan nisan salib yang terjadi di pemakaman umum di Purbayan Kotagede Yogyakarta (17/12/2018), kasus ini menjadi polemik atas legitimasi nilai dan standar nilai dalam kehidupan bermasyarakat berbangsa terkait pluralisme (Priyani, 2021). Kedua, acara sedekah laut di pantai baru, Ngentak, Poncosari, srandakan, Bantul DIY batal diselenggarakan karena sejumlah properti upacara sedekah laut dirusak sekelompok masyarakat, dianggap bermuatan unsur syirik (Pertana, 2018). Ketiga, Slamet Jurniarto, yang berbeda agama dengan masyarakat yang mayoritas muslim tak izinkan warga menetap di dusun Karet, Pleret, Bantul (BBC, 2019). Keempat, kebijakan sekolah yang mewajibkan mengenakan jilbab bagi siswi non muslim di SMA Negeri di Padang (BBC, 2021). Orientasi nilai-nilai yang berkembang di masyarakat telah membawa perubahan mendasar atas pilihan nilai dan hidup dalam melihat realitas yang ada. Kasus pemotongan salib sebagai salah satu bentuk pemahaman atas nilai-nilai yang eksklusif dalam melihat realitas kehidupan berbangsa dan bernegara. Sesuatu bentuk yang berbeda dan tidak sesuai dengan sistem nilai dan keyakinan oleh sekelompok masyarakat termasuk kelompok yang mengatasnamakan agama tertentu dapat menjadi perbuatan yang ekstrim dan dinilai mencederai nilai-nilai keberagaman dan Pancasila. Kasus pemotongan salib atas nisan yang berbeda agama sebagai salah satu bentuk paham radikalisme yang berakar pada praktek paham Takfirisme di masyarakat.

Radikalisme dalam posisi ini setara dengan perilaku teroris dalam pengertian lain mendekati perilaku tindak teroris. Teroris dalam konteks perilaku berarti melakukan aksi dan tindakan konkret, tindakan yang mengarah pada teroris. Yang urgen hukum 
harus didahulukan daripada epistemologi sang pelaku. Epistemologi yang dimaksud Takfirisme. Takfirisme suatu tindakan spontan dengan perkataan yang langsung dengan menghukum orang. Tindakan dan pikirannya menyatakan sesuatu dalam konteks hitam dan putih. Upaya yang dilakukan untuk mencegah gerakan radikalisme dengan menggunakan Pancasila juga sudah dilakukan oleh berbagai kelompok dan komunitas, termasuk lembaga negara dalam bentuk program pelatihan, sosialisasi, deradikalisasi. Satriawan, Islami, Lailam memaparkan program dan kegiatan pencegahan gerakan radikalisme melalui penanaman ideologi Pancasila dan kesadaran konstitusi berbasis komunitas yang dilakukan di beberapa komunitas melalui penguatan ideologi Pancasila di komunitas dan Training for trainers pencegahan gerakan radikalisme dengan pemahaman ideologi Pancasila yang menekan aspek pengetahuan dan pemahaman tentang Pancasila (Satriawan, Islami, \& Lailam, 2019).

\section{Pengertian dan Maksud Metode Pancasila}

Metode Pancasila dalam menangkal radikalisme menjadi pokok pembahasan dan analisis dalam kajian ini karena selama ini Pancasila belum dirumuskan dalam bentuk metode berpikir dan metode kebijakan. Berbagai studi tentang Pancasila dalam merespon persoalan radikalisme masih meletakkan pada dasar pemahaman dan program pelaksanaan kegiatan untuk menanamkan nilai-nilai Pancasila (Hakim \& Ekapti, 2019; Satriawan et al., 2019; Sudjito \& Muhaimin, 2018). Upaya untuk menjadikan Pancasila sebagai standar kriteria dan validitas nilai belum terpikirkan lebih lanjut. Metode yang dimaksud merupakan acuan, referensi untuk menyusun standar kriteria dan validitas nilai yang paling obyektif dan memiliki otoritas. Dalam konteks kehidupan bernegara dan bermasyarakat relasi negara dan warga negara menjadi penting untuk dibangun sistem dan standar yang ideal di tengah tengah kehidupan masyarakat yang majemuk. Metode Pancasila dapat digunakan sebagai upaya untuk menangkal paham radikalisme. Selama ini, metode Pancasila masih dimaknai dalam konteks pembelajaran dan pengajaran tentang Pancasila. Sebagaimana model dan metode pembelajaran penanaman karakter dan nilai-nilai Pancasila melalui role play yang diterapkan oleh pendidik kepada peserta didik yang bertujuan untuk mengajak peserta didik aktif dalam pembelajaran (Nurgiansah, Hendri, \& Khoerudin, 2021; Rachman, Nurgiansyah, \& Kabatiah, 2021).

Pancasila perlu dirumuskan untuk menjadi standar kriteria, validitas dan validasi nilai-nilai yang ada. Sosialisasi kepada masyarakat tentang konsep radikalisme, terorisme, ekstremisme, dan fundamentalisme berkaitan dengan hukum yang berlaku. Penggunaan standar kriteria dan validitas nilai untuk diperbanyak konten konten logis dan penalaran penalaran kebangsaan. Melakukan sosialisasi konten konten ajaran ajaran edukatif yang paham tentang nilai-nilai agama yang memadai, nilai-nilai universal. Sejauh ini kelompok berpaham radikal ini menggunakan cara cara negara dan sumber daya negara untuk melawan negara dan mengkerdilkan peran masyarakat, serta menekan minoritas.

Metode Pancasila dalam menangkal radikalisme dapat dilakukan dengan merumuskan kurikulum Pancasila dan Agama. Substansi di dalam kurikulum Pancasila dan Agama memiliki bangunan untuk membangun harmonisasi konten agama yang dipandu dengan nilai-nilai Pancasila. Materi materi yang perlu diletakkan antara lain: Pancasila dan filsafat Ketuhanan, filsafat manusia, filsafat Pancasila, filsafat kenegaraan 
dan keadilan, dan filsafat politik hikmat. Dalam konteks masyarakat dan keluarga, metode Pancasila dapat dilakukan melalui konten ceramah bertema harmonisasi Pancasila dan tasawuf.

\section{Legitimasi Metode Pancasila}

Berdasarkan hasil penelitian dan permasalahan di atas menunjukkan bahwa persoalan mendasar yang terjadi dan dihadapi oleh masyarakat dewasa ini karena mengalami krisis epistemologi dan masyarakat mengalami masa kegelapan sama halnya dalam konteks memahami perkembangan memahami untuk mencari validitas kebenaran pengetahuan antara kelompok positivistik dan non positivistik yang melahirkan pemikiran antitesa atas legitimasi pengetahuan dan kebenaran (Pratama \& Mutia, 2020). Persoalan legitimasi atas pengetahuan dan kebenaran ini menjadi bagian proses yang secara terus menerus untuk diuji terlebih berkaitan dengan kehidupan bermasyarakat, berbangsa, dan bernegara terutama dalam penentuan nilai-nilai yang sahih dan valid untuk menjadi dasar dan pedoman dalam kehidupan bermasyarakat, berbangsa, dan bernegara. Metode Pancasila dapat dijadikan standar kriteria dan validitas nilai dapat dilakukan melalui strategi pelembagaan nilai-nilai Pancasila.

Kebijakan standarisasi dan validitas nilai yang dibuat negara kemudian diperkuat eksekutif, kemudian diajukan ke legislatif kemudian diserahkan yudikatif. Produk hukum yang lebih objektif. Upaya melakukan tindakan validitas nilai melalui prosesproses kebijakan politik dan hukum. Proses tersebut dilakukan melalui beberapa tahapan yaitu Pancasila merupakan dasar dan kristalisasi nilai dasar sebagai material. Untuk menjadi standar validitas nilai dirumuskan oleh pembuat kebijakan (eksekutif). Setelah dirumuskan oleh eksekutif kemudian disosialisasikan ke legislatif dan terbuka bagi masyarakat. Setelah tuntas dari legislatif kemudian diputuskan bersama setelah tidak ada lagi masukan dan keberatan dari masyarakat atau elit politik yang lain agar menjadi produk Undang Undang yang tidak multi tafsir. Hal ini menjadi produk hukum untuk bisa dilaksanakan sebagai acuan yudikatif dalam melaksanakan dan memutuskan kasus kasus berkaitan dengan benturan nilai dan norma. Proses proses yang dilakukan dalam merumuskan validitas nilai dan standar nilai sampai terjadi proses kesepakatan dapat disaksikan oleh masyarakat karena diskusi dapat dilihat dan diikuti secara live pada media yang telah disediakan. Sehingga tidak terjadi perdebatan lagi di masyarakat atau di kalangan antar legislatif atau eksekutif karena persoalan ini menjadi persoalan negara.

Nilai-nilai Pancasila akan berwibawa dan suci dan tidak berjarak dengan nilai kesucian agama ketika standar kriteria dan validitas nilai itu dilakukan oleh penyelenggara negara dan penegak hukum secara konsisten, proporsional dan tepat. Ketika nilai itu dilaksanakan secara konsisten maka lembaga negara akan terhormat dan berwibawa di mata rakyat. Terjadinya jarak antara nilai-nilai Pancasila dan nilai agama di masyarakat diakibatkan oleh sosialisasi pertentangan antara nilai Pancasila dan nilai kesucian agama. Padahal antara kesucian agama dan kesucian Pancasila itu dapat berjalan harmonis dan tidak berhadap hadapan. Peran lembaga negara seperti Badan Pembinaan Ideologi Pancasila (BPIP) yang baru dibentuk oleh pemerintah tahun 2018 menjadi bagian penting untuk mengawal proses perumusan standar kriteria dan validitas nilai Pancasila. Kebijakan untuk membuat metode Pancasila melakukan standarisasi, validasi nilai. Kebijakan ini harus mengarahkan pada objektivitas. Untuk mendekati

\section{JURNAL KEWARGANEGARAAN}


objektivitas nilai yang menjadi ukuran adalah nilai yang inheren. Untuk itu, lembaga pengawal Pancasila harus berwibawa dan mendapatkan kepercayaan dari masyarakat.

\section{KESIMPULAN}

Radikalisme yang berkembang dan muncul di Indonesia sebagai wujud dari persoalan fundamental tentang legitimasi kebenaran dan nilai-nilai yang harus dianut dan diikuti oleh masyarakat. Munculnya paham Takfirisme telah melahirkan pemahaman, pemaknaan, dan penilaian atas persoalan kehidupan masyarakat yang terjadi menjadi cenderung berpihak nilai-nilai tertentu. Keberpihakan pada nilai-nilai tertentu ini telah berpotensi menimbulkan pada disintegrasi bangsa dan lunturnya nilai-nilai Pancasila. Radikalisme berpotensi menjadi paham yang dapat mengganggu persatuan dan kesatuan bangsa. Metode Pancasila sebagai upaya untuk menangkal radikalisme menjadi sangat penting dan dibutuhkan bagi negara dan masyarakat. Pancasila sebagai sistem nilai dan sistem negara perlu diperkuat dengan pembentukan standar kriteria dan validitas nilai yang dapat dipercaya dan diakui oleh seluruh lapisan masyarakat. Hasil penelitian ini menunjukkan bahwa metode Pancasila sebagai upaya dalam menangkal radikalisme perlu diperkuat dengan perumusan standar kriteria dan validitas nilai.

\section{UCAPAN TERIMA KASIH}

Kami ucapkan terima kasih kepada beberapa pihak yang telah memberikan kontribusi dalam mendukung terwujudnya artikel penelitian ini. Artikel ini diharapkan dapat memberikan sumbangan pemikiran dalam pengembangan kajian dan studi Pancasila dan Kewarganegaraan di Indonesia dalam perspektif geopolitik nasional dan internasional. Penulis juga mengucapkan terima kasih telah diberikan kesempatan untuk mengabdi dan mengajar di Universitas Mercu Buana Yogyakarta pada mata kuliah Pancasila dan Kewarganegaraan. Tulisan ini diharapkan dapat memberikan wawasan bagi mahasiswa pada mata kuliah Pancasila dan Kewarganegaraan. Penulis kedua juga mengucapkan terima kasih dan banyak belajar dari rekan rekan sejawat di Pusat Studi Pancasila Universitas Gadjah Mada.

\section{DAFTAR PUSTAKA}

Ali, A. S. (2009). Negara Pancasila: Jalan Kemaslahatan Berbangsa. Jakarta: LP3ES.

Azra, A. (2016). Transformasi Politik Islam: Radikalisme, Khilafatisme, dan Demokrasi. Jakarta: Prenadamedia.

Bakry, N. M. (2003). Pancasila Yuridis Kenegaraan. Yogyakarta: Liberty.

BBC. (2019). Diusir Dari Desa Karena Agama, Bagaimana Mencegah Intoleransi Ditingkat Warga? Diambil dari www.bbc.com website: https://www.bbc.com/indonesia/indonesia-47801818

BBC. (2021). Wajib Jilbab Bagi Siswi Non-Muslim di Padang: "Sekolah negeri Cenderung Gagal Terapkan Kebhinekaan." Diambil dari https://www.bbc.com/ website: https://www.bbc.com/indonesia/indonesia-55806826 
Gatra. (2017, Juli). Potret Global Relasi Islam-Nasionalisme. Gatra.

Hakim, L., \& Ekapti, R. F. (2019). Penguatan Pendidikan Pancasila Sebagai Jatidiri, Refleksi, dan Tantangan Dalam Membatasi Paham Radikalisme Mahasiswa di Perguruan Tinggi Islam Ponorogo. Muslim Heritage, 4(2), 403-419. https://doi.org/10.21154/muslimheritage.v4i2.1850

Kaelan. (1996). Filsafat Pancasila Disusun Berdasarkan GBPP dan SAP Tahun 1995. Yogyakarta: Paradigma.

Kaelan. (2015). Liberalisasi Ideologi Negara Pancasila. Yogyakarta: Paradigma.

Kaelan. (2016). Pendidikan Pancasila. Yogyakarta: Paradigma.

Kusman, A. P. (2020). Mengawasi "Radikalisme" Pendekatan Kultural dan Kebijakan Illiberal Paska Momen 212. Prisma, 39(1), 16-27.

Munip, A. (2012). Menangkal Radikalisme Agama di Sekolah. Jurnal Pendidikan Islam, 1(2), 159-181. https://doi.org/10.14421/jpi.2012.12.159-181

Muthohirin, N. (2019). Potret Radikalisme Agama di Negara Pancasila. In B. Sabdo (Ed.), Ancaman Radikalisme dalam Negara Pancasila (hal. 123-150). Jakarta: Kompas Gramedia.

Nurgiansah, T. H., Hendri, \& Khoerudin, C. M. (2021). Role Playing dalam Pembelajaran Pendidikan Pancasila dan Kewarganegaraan. Jurnal Kewarganegaraan, 18(1), 5664. https://doi.org/10.24114/jk.v18i1.22597

Pertana, P. R. (2018). Tradisi Sedekah Laut Ditentang, Banyak Kalangan Meradang. Diambil 2 Februari 2021, dari detikNews website: https://news.detik.com/beritajawa-tengah/d-4255648/tradisi-sedekah-laut-ditentang-banyak-kalanganmeradang.

Pratama, F. F., \& Mutia, D. (2020). Paradigma Kualitatif sebagai Landasan Berpikir Pendidikan Kewarganegaraan. Jurnal Kewarganegaraan, 17(1), 51-64. https://doi.org/10.24114/jk.v17i1.18701

Prisma. (2020). Meredam Ketegangan: Agama dan Negara. Prisma: Jurnal Pemikiran Sosial Demokrasi, 39(1).

Priyani, I. D. (2021). Pluralisme Hukum Dalam Penyelesaian Konflik Pemotongan Nisan Salib di Kawasan Purbayan Kota Gede Yogyakarta. Khazanah Multidisiplin, 2(2), 85-100. https://doi.org/10.15575/kl.v2i2.13168

Qodir, Z. (2011). Hubungan Penguasa dan Rakyat dalam Praktik Politik Islam, serta Gagasan Hubungan Agama dan Negara di Indonesia. In J. Mardimin (Ed.), Mempercakapkan Relasi Agama \& Negara, Menata Ulang Hubungan Agama dan Negara di Indonesia (hal. 26-57). Yogyakarta: Pustaka Pelajar.

Qodir, Z. (2014). Radikalisme Agama di Indonesia. Yogyakarta: Pustaka Pelajar.

Rachman, F., Nurgiansyah, T. H., \& Kabatiah, M. (2021). Profilisasi Pendidikan Kewarganegaraan dalam Kurikulum Pendidikan Indonesia. Edukatif: Jurnal Ilmu Pendidikan, 3(5), 2970-2984. https://doi.org/10.31004/edukatif.v3i5.1052

Russian Today. (2021). 5-person ISIS cell in Germany plotted to kill YouTuber, played paintball to hone attack skills - prosecutors. Diambil 2 Februari 2021, dari 
www.rt.com website: https://www.rt.com/news/515615-germany-isis-cellyoutuber-plot/

Satriawan, I., Islami, M. N., \& Lailam, T. (2019). Pencegahan Gerakan Radikalisme melalui Penanaman Ideologi Pancasila dan Budaya Sadar Konstitusi Berbasis Komunitas. Jurnal Surya Masyarakat, $\quad$ 1(2), 99. https://doi.org/10.26714/jsm.1.2.2019.99-110

Sudjito, \& Muhaimin, H. (2018). Membudayakan Nilai-Nilai Pancasila dan Upaya Menangkal Tumbuhnya Radikalisme di Indonesia. WASKITA: Jurnal Pendidikan Nilai dan Pembangunan Karakter, 2(1), 1-16. https://doi.org/10.21776/ub.waskita.2018.002.01.1

Sumarah, I. E. (2011). Kearifan Lokal, Akar Nilai-nilai Pancasila. In S. Kartono (Ed.), Membumikan Pancasila Serpihan Gagasan Pendidik (hal. 1-8). Yogyakarta: Universitas Sanata Dharma.

Umar, A. R. M. (2010). Melacak Akar Radikalisme Islam di Indonesia. Jurnal Ilmu Sosial dan Ilmu Politik, 14(2), 169-186. https://doi.org/10.1158/1541-7786.MCR-070324

Undang-Undang Dasar Negara Kesatuan Republik Indonesia Tahun 1945.

Undang-Undang Republik Indonesia Nomor 12 Tahun 2011 tentang Pembentukan Peraturan Perundang-Undangan.

Undang-Undang Republik Indonesia Nomor 5 Tahun 2018 tentang Perubahan Atas Undang-Undang Nomor 15 Tahun 2003 tentang Penetapan Peraturan Pemerintah Pengganti Undang-Undang Nomor 1 Tahun 2002 tentang Pemberantasan Tindak Pidana Terorisme Menjadi Undang-Undang.

Wicaksono, H., \& Dermawan, M. K. (2020). Alat Ukur Tingkat Radikalisme Berdasarkan Penilaian Kepribadian. Deviance: Jurnal kriminologi, 4(1), 84-102.

Wicaksono, T., \& Perwita, A. A. B. (2020). The Military Industrial Complex In a Developing Country: Lessons from the Republic of Turkey. Jurnal Hubungan Internasional, 9(1), 53-67. https://doi.org/10.18196/hi.91162 